\title{
The Effect of Angkak and Chitosan Amounts on The Organoleptic Properties of Shrimp Corned
}

\author{
Lucia Tri Pangesthi, Lilis Sulandari \\ Department of Home Economics \\ Universitas Negeri Surabaya \\ Surabaya, Indonesia \\ luciapangesthi@unesa.ac.id
}

\begin{abstract}
This study aims to know: 1) the influence on adding the amounts of angkak and chitosan to the organoleptic properties based tenderness, color, flavor, taste, and preferences and 2) nutrients from shrimp corned best applied on angkak and chitosan. This research included a kind of experiment with a single factorial design. Data were collected by 11 skilled panelists from Department of Home Economics Studied Program at Universitas Negeri Surabaya lecturers. The instrument used was observation check list form. The data were analyzed by Friedman test and Multiple Comparison tests to know the effect between the treatments. The proximate test data were analyzed descriptively. The results showed that: 1) There is influence on adding the amount of chitosan and angkak based on tenderness, but not the color, flavor, taste and preferences on corned shrimp; 2) levels of shrimp corned nutrition (in percentage) contains protein for about $19.88, \mathbf{1 0 . 5 1}$ fat, carbohydrate 5.10 and 61.58 water.
\end{abstract}

Keywords-shrimp corned; chitosan; angkak; potassium nitrate; dry cured

\section{INTRODUCTION}

Shrimp corned is preserved animal foods made from minced shrimp through a process of cured with the potassium nitrate, as the substitution of angkak. The use of angkak (Red fermented rice) is intended to anticipate the carcinogenic influences that are accumulated from the use of potassium nitrate. Angkak is red grain rice fermented by Monascuspurpureus [3], functioning as a dye, forming a distinctive taste by the content of oligopeptides and antibacterial properties in some bacteria; Bacillus subtilis, streptococcus, Pseudomonas, and Streptococcus aerus which can simultaneously be used as a preservation [2] [8].

The results of the first year of research related to the application of the use of angkak as a substitution of potassium nitrate $\left(\mathrm{KNO}_{3}\right)$ on corned beef product. It showed that the combination used on $1 \%$ of angkak powder and 200ppm of potassium nitrate give best organoleptic properties which generate revenue and provide protection for potassium nitrate test which is the best results reach 10,51pppm. However, the shelf life of corned beef from microbiology test result by the counting method of cadre reached only 5 days according to SNI quality standard 01-3775-1995. Therefore, in the shrimp corned formula is added with chitosan, so that the product remains safe and able to compete with commercial products on the market. Chitosan is a chitin inheritance product from the process of dehydration of shrimp shells. Chitosan contains polycation that can bind the negative charge of other compounds and easily degrades biologically and nontoxic[12]. With such properties, chitosan is able to inhibit the growth of bacteria and mold or act as bacteriostatic activity [5]. Further, chitosan acts as a bactericidal activity, because of its ability to change the permeability of cell walls or active transport of bacterial cell walls to lysis. The ability of chitosan preservation is selected, since it is a natural preservation that can improve the quality of shrimp corned relatively healthy and food safety.

\section{METHODS}

\section{A. Materials and Tools}

The ingredients used in the manufacture of shrimp corned are: shrimp, angkak powder, potassium nitrate, chitosan, cmc, skim milk powder, tapioca, salad oil, garlic, salt, sugar, pepper and nutmeg. Equipments used are digital scales, knives, plastic container for cradle, refrigerator, steamer, glass container, alluminium foil cup and stove.

\section{B. Shrimp Corned Methods}

Corned beef is made with curing technology using a mixture of cured salt, salt, sugar and beef. The process of curing can be done in two different ways, namely wet and dry curing [11]. The different treatment is in the use of water in the curing process. Curing process begins with trimming, then being washed and drained for 30 minutes. Meanwhile, salt, sugar, angkak powder, chitosan and potassium nitrate are mixed together and evenly distributed in the shrimp surface placed in a plastic container covered and stored in the refrigerator for 48 hours. Further, the shrimp cured dough minced, then put it into aluminum foil cup and cook it by steaming techniques for 20 minutes.

\section{RESULTS AND DISCUSSION}

\section{A. Mean Organoleptic Test}

Based on the mean value of organoleptic properties of shrimp corned made with chitosan $1.5 ; 1.75 ; 2 \%$, angkak powder 0,5 and $0,75 \%$ and $200 \mathrm{ppm}$ potassium nitrate with dry curing method that the highest mean value of 3.64 on the shrimp corned with the use of angkak 0.7 and chitosan 1.75 and $2 \%$ with the criteria of smoothness and immediately spell out in the mouth, 3.64 colors on shrimp corned with use 
angkak 0.5 and $2 \%$ chitosan with red criterion, 3.27 flavor of shrimp corned with angkak 0,75 and chitosan 1.75 and $2 \%$ with sufficiently flavor criteria of shrimp corned, 3.64 taste in shrimp corned with use of angkak 3.64 and chitosan $2 \%$ with the criteria quite acid and preference 3,82 on the shrimp corned with the use of angkak $0,75 \%$ and $2 \%$ chitosan with the criteria preferred.

\section{B. Friedman's Test}

Based on the results of analysis using non parametric Friedman test from the shrimp corned that amount of chitosan used in the manufacture of shrimp corned influence on the resulting tenderness as indicated by the value of $\chi^{2}$ (ChiSquare $)=11,244$ is greater than the value of $\chi^{2}{ }_{0.05(5)}={ }^{11.070}$ with probability $\mathrm{p}=0.47$. It is less than the real level of 0.05 (> $5 \%$ ). However, the amount of chitosan does not have influence on the color as indicated by the value of $\chi^{2}$ (ChiSquare) $=1.893$ less than the value of $\chi_{0.05(5)}^{2}={ }_{1.893}$ with probability $\mathrm{p}=0.864$ greater than the significance level of 0.05 (> 5\%), flavor as indicated by the value of $\chi^{2}$ (chiSquare) $=5.495$ less than the value of $\chi_{0.05(5)}^{2}={ }_{11.070}$ with probability $\mathrm{p}=0.359$ greater than the significance level of 0.05 (> 5\%), taste like as indicated by the value of $\chi^{2}$ (chiSquare $)=7.846$ is greater than the value of $\chi_{0.05(5)}^{2}={ }^{11.070}$ with probability $\mathrm{p}=0.165$ less than the real level of 0.05 (> 5\%) and preferences as indicated by the value $\chi^{2}$ (chi-Square) $=$ 8.826 less than the value of $\chi_{0.05(5)}^{2}={ }^{11.070}$ with probability $p=$ 0.116 greater than the significance level of 0.05 (> 5\%). So the hypothesis that there is influence interaction amount of angkak and chitosan to the acceptability is accepted. Therefore, there is the influence of treatment should be conducted among multiple comparison test.

Further test results show that the amounts of chitosan give a different effect on the shrimp corned produced. In shrimp corned products made from the addition of angkak 0.5 and chitosan 1.75 and $2 \%$ give the best influence on the smoothness. It becomes smooth and immediately spells out in the mouth. The process of binding occurs due to the occurrence of proteolysis in various fractions of meat proteins by acid. Proteolysis results in a reduced protein fraction creating the meat smoothness increased [4][7]. Myofibril proteolysis produces protein fragments with shorter peptide chains. The result of proteolysis in large quantities will multiply dissolved protein content in a dilute salt solution. As a result, the bond between the fiber and breaking the fiber into shorter fragments make the muscle fiber properties more easily separated and make the meat smoother [6].

The shrimp corned effectiveness index test based on the result of Friedman test, showed that the best shrimp corned originated from the addition of angkak 0.5 and $2 \%$ chitosan.

\section{Value of Shrimp Corned Nutrition}

The safety and feasibility of corned beef products need to be assured from the nutritional quality of corned beef products made by chemical test [1]. A proximate test result from the best shrimp corned is presented in Table 1 .

TABLE I. DATA OF SHRIMP CORNED NUTRITION (100 G)
\begin{tabular}{|l|c|c|c|c|}
\hline \multicolumn{1}{|c|}{$\begin{array}{c}\text { Shrimp Corned } \\
\text { Treatment }\end{array}$} & $\begin{array}{c}\text { Protein } \\
(\boldsymbol{\%})\end{array}$ & $\begin{array}{c}\text { Fat } \\
\mathbf{( \% )}\end{array}$ & $\begin{array}{c}\text { Carbo } \\
\mathbf{( \% )}\end{array}$ & $\begin{array}{c}\text { Water } \\
(\mathbf{( \% )})\end{array}$ \\
$\begin{array}{l}\text { Angkak } 0.5 \text { and } \\
\text { Chitosan } 1.75 \%\end{array}$ & 19.88 & 10.51 & 5.10 & 61.58 \\
\hline
\end{tabular}

Based on Table 1., the results of proximate corned shrimp best comes from the addition of treatment angkak 0.5 and $2 \%$ had a protein content of $19.88 \%, 10.51 \%$ fat, carbohydrate $5.10 \%$ and $61.58 \%$ water. The nutritional value of shrimp corned except water is still in accordance with the standard of corned quality according to SNI 01-3775-1995. However, the water content is higher $(0.86 \%)$ than the quality standard by SNI.

\section{CONCLUSION}

- There is an influence on adding amounts of angkak and chitosan to the organoleptic test of tenderness, flavor and taste but not on the organoleptic of color.

- Proximate test of shrimp corned product with addition of Angkak 0,5 and chitosan $2 \%$ have protein content $19,88 \%$, fat $10,51 \%$, carbohydrate $5,10 \%$ and water $61,58 \%$.

- Shrimp corned beans are needed to be followed up by testing the shelf life after being given treatment of commercial packaging application type.

- Shrimp corned products can be increasingly performed to become a commercial product, followed by research on the packaging of commercial corned beef products.

\section{REFERENCES}

[1] AOAC. 1990. Official Methods of Analysis. Fifteenth Edition. Published by the AOAC, Inc., Siute 400, 2200 Wilson Boulevard, Arlington, Virginia 2220, USA.

[2] Blanc, "Production and Food Application of the Red Pigments of Monascus ruber," J.food Sci, vol. 58, pp. 1099-1110, 1993.

[3] Carels, M.and Sherpherd, "The effect of different nitrogen source on pigment production and sporulation of Monascus species in submerged shaken culture," Canadian Journal of Micologia , vol.5, pp. 149-197, 1977

[4] Griffin, D.H.1981. Fungal Physiology. John Wiley and Ss. New York.

[5] Kyu-Lee et al., "Production of red pigments by Monascus purpureus in submerged culture. Biotechnology and bioprocess Engineering" vol.6, pp. 341-346, 2001.

[6] Linn, "Isolation and cultural conditions of Monascus sp for the production of pigment in a submerged cultural," Journal of Fermentation Technology, vol. 5, pp. 135-142, 1973.

[7] Ma, J.,Y. Li, Y. Hua, D. Ju,D. Zhang, R. Cooper, and M. Chang., "Constituents of red yeast rice, a traditional Chinese food and medicine," Journal of Agricultural and Food Chemistry,vol. 48, pp. $5220-5225,2005$.

[8] Su, Y.C. dan Wang, H.W. "Chinese Red Rice Anka. Didalam Handbook of Indigenous Fermented Foods". K H. Streinkraus (ed.) New York: Marcel Dekker Inc, 1977.

[9] Stocking, E.M. dan R.M. Williams, "Chemistry and Biology of biosynthetic Diels Aldier reaction," Angewandte Chemistry International, vol. 42, pp. 3078-3115, 2003.

[10] Wong, H.C, Y.C. Lim, and P.E. Kochler, "Regulation of Growth and pigmentation of Monascus purpureus by carbon and nitrogen consentration," Mycologia vol. 73, pp. 649-564, 1981. 
[11] Mac Con Iomaire, M. and P. Gallagher, "Irish Corned Beef: A Culinary History," Journal of Culinary Science and Technology,vol 9, 2011.

[12] Mohamed E. I. Badawy, Entsar I. Rabea, Nehad E. M. Taktak, and Mahmoud A. M. El Nouby," Production and Properties of Different Molecular Weights of Chitosan from Marine Shrimp Shells".Journal Chitin Chitosan Science, Vol. 4, pp. 46-54, 2016 